\title{
Terminology and Conceptual Apparatus
}

\begin{abstract}
Interpretation lacks sharpness. We see this lack of sharpness both in ordinary discourse and in the literature on the role of interpretation in particular domains, art criticism and legal theory among them. With rare exceptions, the concept is used as an umbrella under which a large variety of otherwise unrelated things fit comfortably. So choosing interpretation as one's focus of attention is risky. It is risky because the pressure to find order can easily lead to a manipulation of the concept with view [sic] to turning it into a tool at one's disposal. ${ }^{189}$
\end{abstract}

\section{Introduction}

Before digging into the details of the domestic judicial practice of international law, some conceptual and terminological clarifications are in order. First of all, what do lawyers - as opposed to musicians, dancers, or physicists, for example - do when they interpret? What do they mean by interpretation (2)? Second, what is judicial interpretation (3) and what is domestic judicial interpretation (4)? Third, I clarify the notion of interpretative method (5). Finally, given that the present study is concerned with the interpretation of international law, it is important to delineate what this body of law encompasses (6).

\section{Legal Interpretation}

Interpretation can be defined, following Andrei Marmor, as the ascription of meaning to an object ${ }^{190}$ (the interpretandum). The object's meaning designates its intelligibility, ie, the features of the object that can be intellectually

\footnotetext{
189 Barradas de Freitas (n 127) 8.

190 Andrei Marmor, Interpretation and Legal Theory (2nd edn, Hart Publishing 2005) 25.
} 
grasped. ${ }^{191}$ Interpretation refers both to the process (or activity) by which meaning is attached to the object and to the result (or outcome) of this process. ${ }^{192}$ As Timothy Endicott puts it, "[a]n interpretation is an answer to the question: "What do you make of this?" '193

Interpretation is by no means specific to the legal realm. We interpret when we read a novel, converse with a friend, attend a religious ceremony, look at a photograph, or try to make sense of scientific data. Comedians, psychologists, and pianists specialize in the interpretation of plays, human behavior, and musical pieces, respectively. As Raquel Barradas de Freitas highlights, the word 'interpretation' is used by 'ornithologists, scientists, anthropologists, artists, astrologers, actors, literary critics, marketing specialists, mathematicians, archaeologists, poets, chefs, musicians, chess players and lawyers.' ${ }^{194}$ Why, then, is legal interpretation special, if at all?

Legal interpretation is different from non-legal interpretation mainly because the law (the interpretandum) is idiosyncratic. ${ }^{195}$ This point may seem trivial, but it is crucial in order to understand what legal interpretation is.

The interpretandum of legal interpretation must be carefully defined at the outset. In and outside legal practice, we commonly talk about legal interpretation as an activity that is about the law. ${ }^{196}$ We usually say that judges (and other actors) interpret the law. The title of this study also refers to the interpretation of international law. In fact, to use the word 'law' (or the notion of 'legal norm') to designate the object of legal interpretation is imprecise. Indeed, one must distinguish between the interpretandum, on the one hand, based on which the law is determined (ie, social facts such as the adoption of documents, the drafting of paragraphs, the conduct of parliamentary deliberations, or even brute natural facts $)^{197}$ and the law, on the other hand, ie, the legal norm that is identified through, and is the outcome of, interpretation, and which is not a social fact. ${ }^{198}$ As Raquel Barradas de Freitas notes, 'legal norms (unlike legal texts)

\footnotetext{
191 Barradas de Freitas (n 127) 31.

192 See ibid 10.

193 Timothy Endicott, 'Putting Interpretation in Its Place' (1994) 13 Law and Philosophy $45^{1,} 45^{1}$.

194 Barradas de Freitas (n 127) 9.

195 This is true even if many objects of legal interpretation exist, which explains why 'judicial interpretation is not defined by its object'. See ibid 193 .

196 As Scott Shapiro notes, we routinely use the word 'law' in myriad ways to designate a variety of objects: Scott J Shapiro, Legality (Belknap Press 2011) $4 \mathrm{ff}$.

197 One example cited by Raquel Barradas de Freitas is the eruption of the volcano Eyjafjallajökull in 2010, which triggered air travel restrictions. See Barradas de Freitas (n 127) 99.

198 See ibid 186.
} 
constitute legal meaning: they are not objects of interpretation. Legal rules and standards are not interpretable'. ${ }^{199}$ She adds that 'anything - from the birth of a baby to a volcanic eruption, from the waving of a hand to a love letter - can potentially have legal meaning. 200

While some features of the law are shared by non-legal objects, others are not. The combination of these features is unique to the law and shapes the interpretation of legal acts in an idiosyncratic way. Some of the characteristics I identify in the next paragraphs presuppose the endorsement of legal positivism or of Raz's theory of authority.

First, law is an intentional object. ${ }^{201}$ It is created by human beings in order to fulfill a particular purpose. In this respect, it is similar to other artistic objects which result from an intentional effort, but dissimilar to natural ones, such as trees, clouds, or birds, for instance - unless one endorses a teleological view of nature, as some natural lawyers do. ${ }^{202}$ It is worth pointing out that non-intentional objects are just as interpretable as intentional ones. ${ }^{203}$ One may think of the interpretation of the movement of clouds, of a chemical reaction, of an old stone, or of medical symptoms, for instance. Relatedly, legal interpretation differs from the interpretation of other objects because of the primary goal its interpreters pursue, namely that of identifying rights, powers, and duties.

Second, law is not only an object, but also a practice. ${ }^{204}$ It is designed to be applied to particular cases, and it is shaped by those who participate in it, especially by its officials who enjoy legal authority and engage in legal interpretation. ${ }^{205}$ This distinguishes legal interpretation from the interpretation of many other objects. A literary critic's interpretation of a novel, for example, does not

199 See ibid 1, 183 ff. Contra Panos Merkouris, 'Interpreting the Customary Rules on Interpretation' (2017) 19 International Community Law Review 126, 128.

200 Barradas de Freitas (n 127) 185.

201 On intentionality, see Robert Stecker, Interpretation and Construction: Art, Speech, and the Law (Blackwell 2003) ch 1. On artefacts, see Barradas de Freitas (n 127) 83 ff.

202 Eg Robert George, 'Natural Law' (2008) 31 Harvard Journal of Law \& Public Policy 171.

203 Barradas de Freitas (n 127) 23.

204 As Samantha Besson writes, '[l]aw is something people do: it is a practice. It is actually something people do together (publicly), and not only on their own: it is a social and accordingly also a political practice'. Samantha Besson, 'International Legal Theory qua Practice of International Law' in Jean d'Aspremont, Tarcisio Gazzini, André Nollkaemper, and Wouter Werner (eds), International Law as a Profession (Cambridge University Press 2017) 6.

205 Raquel Barradas de Freitas defines legal officials as 'people who, in virtue of their professional position, are able to act and speak on behalf of the law', Barradas de Freitas (n 127) 284 . 
shape the meaning of the novel in the way a court ruling does. A literary interpretation does not become part of literature.

Third, law is normative. By giving reasons for action to its subjects, it aims at guiding their behavior. Normativity is not specific to law: morality, tradition, and religion, for instance, also provide individuals with reasons for action. By contrast, the interpretation of a play or a song does not have the purpose of guiding behavior. It can enhance the understanding of the object, but the meaning it conveys is not obligatory. To be obeyed, the law must be capable of being obeyed. Some legal duties, ${ }^{206}$ such as the legal prohibition of arbitrariness, have the purpose of ensuring that the law's subjects are indeed in a position to abide by the law's requirements.

Because courts' decisions are legally authoritative, they display the three aforementioned features: (i) they are intentional objects that carry meaning; (ii) they are part of a practice, which they shape; and (iii) they are normative and obligatory. I now turn to this category of legal interpretation, namely judicial interpretation.

\section{3}

\section{Judicial Interpretation}

In this book, I am concerned with one type of legal interpretation. I am interested in judicial interpretation, or the interpretation of laws by courts (supra, Chapter 1, section 4).

One of the old chestnuts of jurisprudence is whether judicial interpretation does and/or should entail a creative, lawmaking component. The controversy hinges on a deeper disagreement of lawyers and legal scholars about the proper role of courts in the domestic legal order and/or in international law. ${ }^{207}$ In other words, there is agreement on the conceptual core of judicial interpretation, but less so about what judicial interpretations should look like. This issue is complicated by the fact that an interpretation cannot be assessed in the abstract. One must look at specific cases, which are all unique in terms of the facts and legal issues involved.

Scholars use fluctuant terminology to refer to judicial interpretation. The notions of 'application', 'identification', 'ascertainment', and 'determination', to

\footnotetext{
206 Arguably, such duties are also moral duties, yet this aspect is beyond the scope of this book. On this issue: Grant Lamond, 'The Rule of Law' in Andrei Marmor (ed), The Routledge Companion to Philosophy of Law (Routledge 2012).

207 Cass R Sunstein, 'There Is Nothing That Interpretation Just Is' (2015) 30 Constitutional Commentary 193 .
} 
name but a few, are frequently encountered in analyses of judicial interpretation. Given the central place of judicial interpretation in the present study, it is important to clarify at the outset the terminology that I am using, and why.

Judicial interpretation is the ascription of meaning to a legal act by a court (supra, section 2). The term 'interpretation' does not presuppose the endorsement of a specific conception of interpretation (eg interpretation as a strictly mechanistic, non-evaluative act or, at the other end of the spectrum, as an inevitably creative or 'jurisgenerative' activity, as Robert Cover has coined it). ${ }^{208}$

The notion of the application of the law focuses on the stage where the legal act is 'put to use. ${ }^{209}$ It is often employed in a way that glosses over the evaluative and law-creating character of judicial interpretation. A common statement often made to denounce judicial activism - is that judges merely apply, but do not make law. This conception of the judiciary, which has been endorsed by domestic $^{210}$ and international ${ }^{211}$ courts, is often associated with the doctrine of the separation of powers, which requires judges to operate as the 'mouthpiece of the law'. ${ }^{212}$ Yet interpretation is not merely value-free application of the law (and such a view has hardly ever been defended in legal theory anyway). ${ }^{213}$ It is inevitably evaluative. Of course, there is little incentive for courts to openly acknowledge the evaluative judgments their activity requires them to perform, as this candor might undermine their institutional (sociological) legitimacy. This is especially the case in jurisdictions that lack a doctrine of binding precedent (on Switzerland, see infra, Chapter 3, 4.2.7), as opposed to jurisdictions where judicial decisions are, under certain conditions, sources of law.

208 Robert M Cover, 'The Supreme Court, 1982 Term - Foreword: Nomos and Narrative' (1983) 97 Harvard Law Review 4, 11 ff. See also Ingo Venzke, 'The Role of International Courts as Interpreters and Developers of the Law: Working Out the Jurisgenerative Practice of Interpretation' (2011) 34 Loyola of Los Angeles International and Comparative Law Review 99.

209 See the definition of 'application' in <www.merriam-webster.com/dictionary/ application>.

210 In the United States: Marbury v. Madison, 5 U.s. (1 Cranch) 137 (1803), at 177; United States v. Butler, 297 U.s. 1 (1936), at $62 \mathrm{f}$.

211 ICJ, Legality of the Threat or Use of Nuclear Weapons, advisory opinion, 8 July 1996, ICJ Reports 1996, 226, at 237, para 18.

212 Montesquieu, De l'esprit des lois (Garnier 1868) 149.

213 One author endorsing this position is John Maxcy Zane, see Scott Brewer, 'Exemplary Reasoning: Semantics, Pragmatics, and the Rational Force of Legal Argument by Analogy' (1996) 109 Harvard Law Review 923, 943, footnote 59. 
While every application of the law requires interpretation, ${ }^{214}$ not every lawapplying act raises salient and difficult interpretative issues. Moreover, legal interpretation is not necessarily conducted with a view to applying the law, as advisory opinions illustrate. ${ }^{215}$ Finally, it must be added that the application of the law is not the monopoly of the judiciary, since law-applying authorities include both courts and executive (or administrative) authorities.

A related notion that must be distinguished from legal interpretation is enforcement, ie, the act through which the rights and duties of legal subjects are pointed out. Contrary to what is often assumed, coercion is not a necessary feature of enforcement. As Samantha Besson notes, courts are not always involved in the coercive enforcement of their own judgments, yet their interpretations contribute to enforcing the law. ${ }^{216}$ Enforcement logically takes place after the law has been interpreted. Relatedly, obedience (or the synonymous terms of respect, abidance, adherence, or compliance) with the law is only possible if the meaning of the law (and hence the content of the obligation) is reasonably precise. Another term that is often employed as a synonym for enforcement is implementation, although one could use 'implementation' in a more specific way to designate compliance with the law by the law's subject(s), as Antonios Tzanakopoulos and Eleni Methymaki suggest. Enforcement, by contrast, is typically performed by other actors than the law's addressees (although these other actors may be under the obligation to respect this law as well). ${ }^{217}$

Notions such as identification, ascertainment, and determination connote the active, law-creating dimension of interpretation. They suggest that the meaning of the interpretandum needs to be discovered, unveiled, or recognized, as if interpretation were an archaeological exercise. ${ }^{218}$ These terms also

214 Besson, 'Legal Philosophical Issues of International Adjudication: Getting Over the Amour Impossible Between International Law and International Adjudication' (n 85) 420; Frederick Schauer, Playing by the Rules: A Philosophical Examination of RuleBased Decision-Making in Law and in Life (Clarendon Press 1991) 207 f. Schauer's notion of law application includes cases in which the law's subjects follow the law.

215 On this point, see 'Article 19. Interpretation of Treaties' (n 121) $938 \mathrm{f}$.

216 Samantha Besson, 'International Judges as Dispute-Settlers and Law-Enforcers: From International Law Without Courts to International Courts Without Law' (2011) 34 Loyola of Los Angeles International and Comparative Law Review 33, $37 \mathrm{f}$.

217 Antonios Tzanakopoulos and Eleni Methymaki, 'Sources and the Enforcement of International Law: Domestic Courts - Another Brick in the Wall?' in Samantha Besson and Jean d'Aspremont (eds), The Oxford Handbook on the Sources of International Law (Oxford University Press 2017) 6, 9.

218 Ingo Venzke, 'Semantic Authority, Legal Change and the Dynamics of International Law' (2015) 12 No Foundations $1,1$. 
reflect the fact that this meaning needs to be actively defined, that reasons must be offered to justify why the interpretandum means X. Duncan Hollis for instance considers that interpretation performs an 'existential function' in international law regardless of the source at stake. ${ }^{219}$ This dimension of the interpretative process can be compared to what Ronald Dworkin, in domestic legal theory, calls the pre-interpretive stage. ${ }^{220}$ Hollis's conception of interpretation is convincing to the extent that it also takes into account the aspect of content-determination, even if existential interpretation is always 'lurking in the background', as he puts it. ${ }^{221}$ In this vein, Jean d'Aspremont differentiates between 'law ascertainment' (ie, the identification of the legal act) and 'content determination' (the identification of its content or meaning). ${ }^{222}$ This distinction is compelling if these two dimensions of interpretation are not seen as mutually exclusive, but complementary and often intermingled in practice, as d'Aspremont himself acknowledges, ${ }^{223}$ especially with regard to unwritten law. ${ }^{224}$ The aforementioned three terms (identification, ascertainment, and determination) are often used in relation to unwritten international law. The ILC's work on custom refers to the 'identification of customary international law', 225 as do scholars interested in the issue. ${ }^{226}$ Scholars mostly use the notion of 'determination' to refer to $\mathrm{CIL},{ }^{227}$ though they occasionally resort to it in connection with international legal acts in general. ${ }^{28}$ The notion of 'ascertainment' is less

219 Duncan B Hollis, 'The Existential Function of Interpretation in International Law' in Andrea Bianchi, Daniel Peat, and Matthew Windsor (eds), Interpretation in International Law (Oxford University Press 2015). See also Duncan B Hollis, 'Sources in Interpretation Theories: An Interdependent Relationship' in Samantha Besson and Jean d'Aspremont (eds), The Oxford Handbook on the Sources of International Law (Oxford University Press 2017).

220 See Hollis, 'Sources in Interpretation Theories: An Interdependent Relationship' (n 219) 4; Dworkin (n 77) 65 f.

221 Hollis, 'Sources in Interpretation Theories: An Interdependent Relationship' (n 219) 6.

222 Jean d'Aspremont, 'The Multidimensional Process of Interpretation:Content-Determination and Law-Ascertainment Distinguished' in Andrea Bianchi, Daniel Peat, and Matthew Windsor (eds), Interpretation in International Law (Cambridge University Press 2015).

223 See ibid 118.

224 Jean d'Aspremont, 'The International Court of Justice, the Whales, and the Blurring of the Lines Between Sources and Interpretation' (2016) 27 European Journal of International Law $1027,1041$.

225 See <legal.un.org/ilc/guide/1_13.shtml>; Besson and Ammann (n 6o).

226 Alvarez-Jiménez (n 179); Patrick Dumberry, The Formation and Identification of Rules of Customary International Law in International Investment Law (Cambridge University Press 2016). On these notions: Besson and Ammann (n 6o) 7-9.

227 Talmon (n 73); Stirling-Zanda (n 102).

228 d'Aspremont, 'The Multidimensional Process of Interpretation: Content-Determination and Law-Ascertainment Distinguished' (n 222). 
frequently employed. ${ }^{229}$ It pervades Jean d'Aspremont's monograph on the 'ascertainment of legal rules.'. 230

Many scholars are reluctant to refer to the 'interpretation' of customary (international) law, presumably because it is vaguer than written law (which is fixed on a physical medium). Thus, judicial decision-makers arguably have to play a more active part in interpreting it. However, another reason for this reluctance to talk about 'interpretation' is that interpretation is erroneously associated with textual material. Yet interpretation, qua inquiry into the meaning of a legal act, allows us to identify written and unwritten laws alike. Moreover, all laws, written or unwritten, leave room for indeterminacy (infra, Chapter 5, 4.1). Finally, the identification of a legal act (ie, the dimension of law ascertainment) coexists with the identification of its meaning, be it a written legal act or not.

In the present analysis, I predominantly refer to the notion of 'interpretation', at least as regards written international law. For unwritten international law, the use of terms such as 'identification', 'determination', and 'ascertainment' is common and seems appropriate, as these notions denote the greater involvement of the judiciary (and of other authorities) in establishing the existence of the law compared to what is the case with regard to written law. However, it is important to stress that in all these cases, the same operation namely interpretation ${ }^{231}-$ is at stake. ${ }^{232}$

Interpretation is conceptually distinct from the formation of the law (ie, the process of its creation), even if both can overlap in practice (see especially

229 Cedric MJ Ryngaert and Duco W Hora Siccama, 'Ascertaining Customary International Law: An Inquiry Into the Methods Used by Domestic Courts' (2018) 65 Netherlands International Law Review 1.

230 Jean d'Aspremont, Formalism and the Sources of International Law: A Theory of the Ascertainment of Legal Rules (Oxford University Press 2011).

231 On the interpretability of custom, see the dissenting opinion of Judge Tanaka in ICJ, North Sea Continental Shelf (Federal Republic of Germany v. Denmark; Federal Republic of Germany v. Netherlands), Judgment, ICJ Reports 1969, 3, at 181; ILA, 'Preliminary Report of the ILA Study Group on the Content and Evolution of the Rules of Interpretation' (2016) 8 <www.ila-hq.org/index.php/study-groups>; Hollis, 'Sources in Interpretation Theories: An Interdependent Relationship' (n 219); Panos Merkouris, 'Interpretation of Customary International Law: The Rules of the Game' (Oxford Public International Law Discussion Group, 2016) <www.law.ox.ac.uk/research-subject-groups/ graduate-discussion-group-index/public-international-law-discussion-group-o>; Merkouris (n 199).

232 ILA, 'Preliminary Report of the ILA Study Group on Principles on the Engagement of Domestic Courts With International Law' (n 61) 9. 
Chapter 3, 4.2.7, and Chapter 4, 3., infra, on the domestic and international legal effect of domestic rulings, respectively).

This study deals with a specific type of judicial interpretation, ie, legal interpretation as practiced by domestic courts (see also supra, Chapter 1, section 5 ).

A domestic court (or judicial body) is a permanent institution established by the law of a particular State and legally tasked with resolving legal disputes in a way that, unless the decision is appealed, is authoritative for the domestic legal order. ${ }^{233}$ Domestic laws (but also many of States' international obligations) usually require that courts resolve such disputes in an impartial, independent fashion, by providing reasons for their decisions, and that their decisions can in principle be appealed to a higher domestic judicial body (eg infra, Chapter 3 , section 4, regarding the Swiss judiciary). These decisions can sometimes also be challenged before an international court. As mentioned (supra, Chapter 1, section 5), domestic courts, unlike international ones, interpret international and domestic law, in the latter case either in its 'original' form (in monist States) or in its domesticated form (in dualist States).

International courts, by contrast, are established by laws created by several States (and, in many cases, under the auspices of an IO). They are legally tasked with resolving legal disputes in a way that is authoritative ${ }^{234}$ for their parties. As previously noted (supra, Chapter 1 , section 5), international courts have a limited jurisdiction, and they cannot in principle interpret domestic law. The PCIJ has famously considered that '[f]rom the standpoint of International Law and of the Court which is its organ, municipal laws are merely facts which express the will and constitute the activities of States, in the same manner as do legal decisions or administrative measures.' ${ }^{235}$ Similarly, the ICJ has held that

233 The ILC Secretariat defines domestic courts as 'all judicial organs exercising their functions within the domestic legal order, regardless of their position in the national system'. See ILC Secretariat, 'Identification of Customary International Law: The Role of Decisions of National Courts in the Case Law of International Courts and Tribunals of a Universal Character for the Purpose of the Determination of Customary International Law' ( $\mathrm{n}$ 185) 3 para 4 .

234 Of course, the modalities of this legal authority and the means deployed to achieve compliance with decisions of international courts vary greatly.

235 PCIJ, case concerning Certain German Interests in Polish Upper Silesia, merits, judgment No 7, PCIJ Series A No 7, 25 May 1926, 4, at 19. See also the individual opinion of Judge Anzilotti in PCIJ, case concerning the Consistency of Certain Danzig Legislative Decrees 
'it is for each State, in the first instance, to interpret its own domestic law. The Court does not, in principle, have the power to substitute its own interpretation for that of the national authorities, especially when that interpretation is given by the highest national courts.'. 236

Sometimes, the application of domestic law by these international courts is inevitable, ${ }^{237}$ eg when the State's compliance with international law needs to be appraised, ${ }^{238}$ or when a given issue is governed by domestic law, like the law of nationality, corporate law, or migration law. Although the PCIJ has generally endeavored to stick to the interpretation of domestic law as defined by domestic courts, unless this interpretation was 'uncertain or divided', ${ }^{239}$ the Court has, as Jean d'Aspremont shows, interpreted domestic law autonomously in a series of cases. ${ }^{240}$ Similarly, while the ICJ defers to the national authorities with regard to the interpretation of domestic law unless an interpretation is 'manifestly incorrect', 241 this has not prevented it from finding that the domestic authorities had failed to act in accordance with domestic law in several cases. $^{242}$

When contrasting international and domestic courts, it is also worth noting that from the perspective of international law, the legal authority of international courts has a wider scope than that of domestic courts, as international rulings can bind multiple States. A single domestic ruling, by contrast, is not a source of international law and, hence, cannot bind another State.

With the Constitution of the Free City, advisory opinion, PCIJ Series A/в No 65, 4 December 1935,60 , at $61 \mathrm{f}$, para 2 .

236 ICJ, case concerning Ahmadou Sadio Diallo (Republic of Guinea v. Democratic Republic of the Congo), merits, judgment, ICJ Reports 2010, 639, at 665, para 70. See also Philip V Tisne, 'The ICJ and Municipal Law: The Precedential Effect of the Avena and Lagrand Decisions in U.s. Courts' (2005) 29 Fordham International Law Journal 865, 907.

237 PCIJ, case concerning the Payment in Gold of Brazilian Federal Loans Contracted in France, judgment No 15, PCIJ Series A No 21, 12 July 1929, 93, at 124.

238 PCIJ, case concerning Certain German Interests in Polish Upper Silesia, merits, judgment No 7, PCIJ Series A No 7, 25 May 1926, 4, at 19.

239 PCIJ, case concerning the Payment in Gold of Brazilian Federal Loans Contracted in France, judgment No 15, PCIJ Series A No 21, 12 July 1929, 93, at 124.

240 See Jean d'Aspremont, 'The Permanent Court of International Justice and Domestic Courts: A Variation in Roles' In Malgosia Fitzmaurice and Christian J Tams (eds), Legacies of the Permanent Court of International Justice (Martinus Nijhoff 2013) $231 \mathrm{ff}$.

241 ICJ, case concerning Ahmadou Sadio Diallo (Republic of Guinea v. Democratic Republic of the Congo), merits, judgment, ICJ Reports 2010, 639, at 665, para 70.

242 Ibid, at 666, para 73 . 
A method is a way of doing something. ${ }^{243}$ Methods of legal interpretation are ways of ascertaining laws. The use of some methods is legally required. It is on these methods, and on the legal norms that require their use, that I will focus in the following paragraphs.

It is important to distinguish the concept of (legally required) interpretative methods from related concepts (infra, 5.1-5.5). The notion of method is, indeed, used loosely and inconsistently in legal practice and scholarship. As a result, lawyers and legal scholars often talk at cross-purposes when they argue about interpretative reasoning. Thus, conceptual clarity is needed.

While they are often conflated in practice, legal norms that require the use of specific interpretative methods must be distinguished from normative interpretative theories (5.1), axiological and structural interpretative principles (5.2), rules (5.3), auxiliary means (5.4), and argument types (5.5). I use the term 'interpretative methods' interchangeably with interpretative canons, maxims, guidelines, and principles (except for axiological or structural principles, infra, 5.2). A canon is an accepted normative principle. ${ }^{244} \mathrm{~A}$ maxim is a fundamental principle of conduct. ${ }^{245}$ Finally, a guideline is an indication or outline of policy or conduct. 246

\subsection{Normative Interpretative Theories}

Legal norms that require the use of interpretative methods, eg textual or teleological interpretation, are not normative interpretative theories (or methodologies) such as textualism or purposivism. Methods are conceptually distinct from what Olivier Corten calls 'objectivist' versus 'voluntarist' theories, which demand that laws be interpreted either separately from, or based on, the intention of their authors. ${ }^{247}$ They are distinct from deontological versus utilitarian interpretative theories, which hinge on the moral philosophy the interpreter endorses. They also differ from what, in international law, is called 'restrictive

243 As mentioned (supra, Chapter 1, section 7), a method is a 'systematic procedure, technique, or mode of inquiry employed by or proper to a particular discipline or art', ie, a reasoned, ordered process. See <www.merriam-webster.com/dictionary/method $>$.

244 See the definition of 'canon' in <www.merriam-webster.com/dictionary/canon $>$.

$245<$ www.merriam-webster.com/dictionary/maxim $>$.

$246<$ <ww.merriam-webster.com/dictionary/guideline>.

247 Olivier Corten, 'Les techniques reproduites aux articles 31 à 33 des Conventions de Vienne : approche objectiviste ou approche volontariste de l'interprétation?' (2011) 115 Revue générale de droit international public, Dossier : Les techniques interprétatives de la norme internationale 351 . 
interpretation', a theory requiring that international law be interpreted so as to least interfere with a State's sovereignty. ${ }^{248}$

Normative interpretative theories mandate giving priority to a specific aspect of the interpretandum, such as its wording or drafting history, or so as to produce a particular result. They do not require that their users develop an elaborate normative framework: their endorsement is often implicit in judicial practice. Just like methods, normative interpretative theories exist in domestic and international law. ${ }^{249}$

Legal norms that prescribe the use of certain methods, by contrast, demand that decision-makers ascertain the law based on some features of the interpretandum. However, although there are categorical reasons for using these specific methods, interpretative norms do not typically provide categorical reasons for action. ${ }^{250}$ In other terms, norms requiring the use of specific methods do not provide a meta-principle that directs how to choose among the different directions in which various methods point. They merely mandate using some features of the interpretandum.

\subsection{Structural and Axiological Interpretative Principles}

Interpretative norms are a subcategory of legal principles. Principles are mandatory norms governing the interpretation of other legal acts, and are drafted at a relatively high level of generality and abstractness. A principle 'states a reason which argues in one direction, but does not necessitate a particular decision'. ${ }^{251}$ While principles do not prescribe the outcome of a case, they orient and therefore constrain interpretative reasoning. Principles can be defeated by other, incompatible principles, provided there are good reasons for which these other principles must prevail.

248 On restrictive interpretation, see Luigi Crema, 'Disappearance and New Sightings of Restrictive Interpretation(s)' (2010) 21 European Journal of International Law 681; Hersch Lauterpacht, 'Restrictive Interpretation and the Principle of Effectiveness in the Interpretation of Treaties' (1949) 26 British Yearbook of International Law 48; Rogoff (n 183) $607 \mathrm{ff}$. For a rejection of this theory, see ICSID, Aguas del Tunari sA v. Bolivia, Decision on Respondent's Objections to Jurisdiction, ICSID Case No ARB/O2/3, 21 October 2005, at para 91.

249 Joost Pauwelyn and Manfred Elsig for instance note that international courts interpret treaties based on a 'dominant hermeneutic'. See Joost Pauwelyn and Manfred Elsig, 'The Politics of Treaty Interpretation: Variations and Explanations Across International Tribunals' in Jeffrey L Dunoff and Mark A Pollack (eds), Interdisciplinary Perspectives on International Law and International Relations (Cambridge University Press 2013).

$250 \quad$ Eg Murphy (n 84) 32.

251 Ronald Dworkin, Taking Rights Seriously (Harvard University Press 1977) 26. 
Norms prescribing the use of interpretative methods must be distinguished from another subcategory of principles, namely structural and axiological principles. These principles encapsulate a form of political organization or a value that judges must take into account when interpreting the law. In domestic law, such principles include the constitutional principles of proportionality, subsidiarity, and equality. ${ }^{252}$ In international law, structural and axiological principles can (but need not) qualify as general principles of international law. They include the principle of good faith, for instance, which is a general principle in the sense of art. 38(1)(d) ICJ Statute, and the principle of complementarity, 253 which is not a general principle of international law.

Contrary to norms on interpretative methods, which point to features of the law that decision-makers must rely on, structural and axiological principles provide criteria that interpreters must use when choosing among different possible interpretations.

\subsection{Rules}

In practice, norms prescribing the use of interpretative methods are often called 'rules'. This is likely due to the fact that the use of methods is required by legal norms, which include rules. ${ }^{254}$ However, the two concepts are distinct.

Legal rules define what conduct is legally permissible. Once the facts have been established, legal rules can be applied to them in a syllogistic fashion..$^{255}$ Although rules, like every legal act, are open-textured and can thus become vague in particular cases, they allow for deductive reasoning once they have been interpreted. Examples of interpretative rules include conflict rules (eg lex specialis or lex posterior) and rules of logic (eg a fortiori or ejusdem generis; on argument types, see infra, $5 \cdot 5) \cdot{ }^{256}$

252 Eg in Switzerland, the constitutional principle of the rule of law (art. 5 Cst.) or the constitutional principle of subsidiarity (art. 5 a Cst.).

253 Art. 17 ICC Statute.

254 Art. 31 VCLT for instance is entitled 'general rule of interpretation'. Contra Klabbers, 'Virtuous Interpretation' (n 93).

255 Hart and Sacks (n 155) 155.

256 Robert Kolb refers to such rules of logic as 'arguments' lawyers use for interpretative purposes: Robert Kolb, 'Is There a Subject-Matter Ontology in Interpretation of International Legal Norms?' in Mads Andenas and Eirik Bjorge (eds), A Farewell to Fragmentation: Reassertion and Convergence in International Law (Cambridge University Press 2015) 475. For a detailed analysis of a range of such rules (labelled 'canons and principles'), see Joseph Klingler, Yuri Parkhomenko, and Constantinos Salonidis (eds), Between the Lines of the Vienna Convention? Canons and Other Principles of Interpretation in Public International Law (Kluwer Law International 2018). 
Norms that prescribe the use of interpretative methods, by contrast, can seldom (if at all) be applied deductively. They are not 'iron-clad rules'257 that determine the outcome of judicial interpretation. Instead, they point to relevant features of the interpretandum that decision-makers must take into account, and they require inductive reasoning (eg to determine the context or legislative history of a legal act).

\subsection{Auxiliary Means}

Auxiliary means assist decision-makers in ascertaining the law. They are not sources of law, but material that helps interpreters in the identification of the law. In other words, auxiliary means are distinct from elements which (objectively) contribute to the formation and evolution of the law, even if they can influence these processes. One example of auxiliary means, under Swiss law, is 'established doctrine and case law', ${ }^{258}$ which Swiss judges must follow when filling gaps.

Norms that mandate the use of interpretative methods and auxiliary means are related. Auxiliary means may be necessary in order to use a given method. A judge may for example need to consult auxiliary means to identify the object and purpose or legislative history of a domestic statute or treaty. Moreover, methods, like auxiliary means, assist interpreters in ascertaining the law. However, unlike methods, auxiliary means are not features of the law that judges must take into account when interpreting it. Instead, they help decision-makers in their interpretative task.

\subsection{Argument Types}

A last distinction concerns norms prescribing the use of interpretative methods, versus what Scott Brewer calls argument types, ie, patterns of reasoning. Scott Brewer lists four basic argument types: deduction, induction, analogy, and inference to the best explanation (or abduction). ${ }^{259}$

Scholars often refer to the inductive versus deductive method, and some have analyzed the practice of international law through the lens of such argument types. ${ }^{260}$ The notion of method I refer to in this study is distinct from argument types, however. Indeed, a given method can be deployed through

257 'Article 19. Interpretation of Treaties' (n 121) 947.

$25^{8}$ Art. 1(3) scc.

259 Brewer (n 213) $942 \mathrm{ff}$.

26o Eg Talmon (n 73). See also Anthea Roberts, 'Traditional and Modern Approaches to Customary International Law: A Reconciliation' (2001) 95 American Journal of International Law 751. 
various argument types. An argument type does not tell judicial decisionmakers to which features of the law they must attend. Instead, it determines the logical structure their reasoning must adopt.

This book deals with the interpretation of international law. It is therefore essential to clarify the notions of 'international legal act' (the interpretandum) and 'international law' (the result of the interpretation of an international legal act). As previously noted (supra, section 2), 'law' and 'legal act' are distinct concepts, even if the term 'law' is often used loosely to designate the legal act (the interpretative object).

The present study primarily looks at the interpretation of public international law. I hence often use the term 'international law' as shorthand for 'public international law'. Public international law, defined narrowly, designates the set of norms resulting from legal acts that govern interstate relations. Yet in contemporary scholarship and international legal practice, the term is employed more broadly to refer to norms resulting from legal acts that govern the relations between different subjects of international law, the behavior of international legal subjects within their jurisdiction and, sometimes, the behavior of individuals. ${ }^{261}$ The bottom line is that these norms are the result of international lawmaking processes, ie, processes involving the organs of more than one State.

Private international law, on the other hand, is the body of domestic and international legal norms that determine the legal rights and duties of individuals in situations with a cross-border dimension. It addresses issues such as the jurisdiction of domestic courts, the applicable law, and/or the conditions for the recognition and enforcement of foreign judgments in such cases. ${ }^{262}$ André Nollkaemper notes that looking at private international law cases where 'the interests of the state are not as immediately involved as they are in public law cases that challenge governmental power alters the stakes dramatically'. 63

While public international law is my primary focus, the claims I defend in this book - namely that domestic courts must take the interpretative methods

261 See the definitions listed in Besson, Droit international public : Abrégé de cours et résumés de jurisprudence (n 89) 2.

262 See for instance art. 1 of the Federal Act on Private International Law of 18 December 1987 (SR 291).

263 Nollkaemper, 'The Duality of Direct Effect of International Law' (n 59) 109. 
of international law more seriously, and that they must strive to reason predictably, clearly, and consistently - apply to public and private international law alike. An in-depth study of Swiss courts' rulings on private international law $^{264}$ (and the extent to which private international law raises distinctive interpretative issues) is beyond the scope of my project, though these rulings have been taken into account in the overview and evaluation of the Swiss practice (infra, Chapters 7 and 8).

International law is law. ${ }^{265}$ Hence, it could be argued that the interpretation of international law shares the features of the interpretation of domestic law. Indeed, international and domestic law tend to overlap not only in terms of their respective subject matters, but also as regards the authorities that apply them (in most cases, domestic authorities, including courts, see also supra, Chapter 1, section 5). However, as previously emphasized (supra, Chapter 1, section 6), international law differs from domestic law in one important respect, namely with regard to the characteristics of (and especially the actors involved in) international lawmaking. Art. 38 ICJ Statute, which, in the practice of international law, is taken to have customary status, lists three sources of international law, ie, treaties, CIL, and general principles. Judicial decisions and scholarly writings, by contrast, are not sources, but 'subsidiary means' (art. 38(1)(d) ICJ Statute), what I call auxiliary means (infra, Chapter 4, 3.2). I analyze the place of domestic judicial decisions from the perspective of art. 38 ICJ Statute in Chapter 4 (infra).

Contrary to the processes through which domestic law is created, which involve the State's legislative branch (and, to an extent that varies from one legal

264 On this issue, see Cashin Ritaine (n 101); Niklaus Meier, 'Auslegungseinheit von LugÜ und EuGVVO unter besonderer Berücksichtigung der Schweizer Beteiligung am Vorabentscheidungsverfahren vor dem EuGH' (2012) 22 Schweizerische Zeitschrift für internationales und europäisches Recht / Revue suisse de droit international et de droit européen 633; Andreas Bucher, 'Que devient le droit (civil) international au Tribunal fédéral ?' Jusletter of 8 May 2017.

265 Hart (n 78) 216 ff; Hans Kelsen, 'Lecture III: International Law and the State', Law and Peace in International Relations: The Oliver Wendell Holmes Lectures, 1940-41 (Harvard University Press 1942). Contra John Austin, The Province of Jurisprudence Determined (John Murray 1832). See also Anthony D’Amato, 'Is International Law Really "Law"?' (1984) 79 Northwestern University Law Review 1293. For a more recent piece on the topic, see Frédéric Mégret, 'International Law as Law' in James Crawford and Martti Koskenniemi (eds), The Cambridge Companion to International Law (Cambridge University Press 2012). While defending the truth of the proposition that 'international law is law' is beyond the scope of this study, international law can be characterized as law because it is (i) an intentional object, (ii) a practice, and (iii) normative and obligatory (supra, section 2). 
order to the other, the State's executive and judicial branch), international lawmaking processes typically and primarily take place through the participation of the organs of various States (which, in some cases, act in the framework of an IO). ${ }^{266}$ The interpretation of international law therefore requires looking beyond one particular jurisdiction, eg when courts inquire into the travaux préparatoires of a treaty or into the ordinary meaning of its text, but also when they ascertain unwritten international law.

In recent years, some scholars have criticized the 'placative confidence' with which most participants in the practice of international law approach the question of what the sources of international law are (ie, their often uncritical reliance on art. 38 ICJ Statute). ${ }^{267}$ A number of authors have tried to provide a broader concept of international lawmaking than the usual reference to art. 38 ICJ Statute, ${ }^{268}$ eg by highlighting that this provision is not exhaustive. ${ }^{269}$ Harold Koh has developed the notion of 'transnational legal process'270 to emphasize the multifaceted nature of international legal practice. It is indeed important to acknowledge the existence of 'informal' international lawmaking 271 and what Prosper Weil, in a seminal article published in the early 1980s, called the 'relative normativity' of international law (and especially the fact that international law includes jus cogens but also - according to some authors - soft law). ${ }^{272}$ For reasons of scope, and given the numerous non-state actors that influence the formation and evolution of international law, this study focuses on the formal sources of international law listed in art. 38 ICJ Statute. It does not

266 As Samantha Besson notes, what distinguishes international law and domestic law are their respective sources, see Besson, 'Theorizing the Sources of International Law' (n 151) 167 .

267 See ibid 164.

268 Alan Boyle and Christine Chinkin, The Making of International Law (Oxford University Press 2007); Joost Pauwelyn, Ramses A Wessel, and Jan Wouters (eds), Informal International Lawmaking (Oxford University Press 2012).

269 Arajärvi (n 37) 30.

270 The term designates 'the theory and practice of how public and private actors - nationstates, international organizations, multinational enterprises, non-governmental organizations, and private individuals - interact in a variety of public and private, domestic and international fora to make, interpret, enforce, and ultimately, internalize rules of transnational law'; Harold Hongju Koh, 'Transnational Legal Process' (1996) 75 Nebraska Law Review $181,183 \mathrm{f}$.

271 Rüdiger Wolfrum, 'Sources of International Law', Max Planck Encyclopedia of Public International Law (Online Edition) (Oxford University Press 2011) para $10<$ opil.ouplaw. com>. Wolfrum accepts the existence of other sources beyond those listed in the ICJ Statute.

272 Prosper Weil, 'Towards Relative Normativity in International Law?' (1983) 77 American Journal of International Law 413. 
look at processes that influence international lawmaking without qualifying as formal sources or auxiliary means.

The notion of international law used in this book - and in the bulk of contemporary international and EU legal scholarship ${ }^{273}$ - does not encompass EU law. While what today is called the EU was created through a network of international treaties, its Court of Justice soon clarified that these treaties had created a legal order of its own. The EU is reluctant to embrace the categories of international law, and the law that governs its legal order belongs to a regime sui generis. However, Switzerland is tied to the EU through several bilateral treaties, which are taken into account in this book. ${ }^{274}$

273 On the (ambivalent) relationship between the EU and international law, see Samantha Besson and Nicolas Levrat (eds), L'Union européenne et le droit international / The European Union and International Law (Schulthess 2015).

274 Of course, the fact that the EU is not a State, but a new legal order of international law may have implications for the way agreements with the EU must be interpreted. On this issue, see Besson and Ammann (n 97). 